\title{
Pengaruh Implementasi Standar Akuntansi Pemerintahan (SAP) dan Sistem Pengendalian Intern Pemerintah (SPIP) terhadap Kualitas Laporan Keuangan pada Pemerintahan Daerah Kabupaten Kuningan
}

\author{
Nunung Suhaeti.,SE \\ Dadang Suhendar.,SE.,M.Si \\ (dadang.suhendar@yahoo.com) \\ Universitas Kuningan
}

\begin{abstract}
This research is done at kuningan District, it began on February until May 2015, this research aimed to knowing the Effect of the Implementation of Government Accounting Standards and Internal Control System of Government on the Quality of Financial Report. This research used descriptive research method and verificative data collecting method which used quisioner, research objectis 37 respondents whom the chief of area work unit at Kuningan, sampling methods used research sampling techniques.

Data refineries technique used this research is Spearman Rank correlation technique. Based on the Spearman Rank correlation coefficient calculation partially for $X_{1}$ with using $Y$ about 0,831 it means there is strong connection between the Implementation of Government Accounting Standards with Quality of Financial Report (SAP). While for $X_{2}$ with Y about 0,917 it means that there is strong connection between Internal Control System of Government with Quality of Financial Report (SPIP). Simultaneous correlation coefficient based analysis result is taken summary that the Implementation of Government Accounting Standard (SAP) and Internal Control Systems of Government on the Quality of Financial Report (SPIP) be important Effect toward quality of Financial reports. While based on this counting can be known determination coefficient ( $r 2$ ) is 90,30 \%. This thing showed that the Effect is given by variable of Implementation of Government Accounting Standards (SAP) and Internal Control System of Government on the Quality of Financial Report (SPIP). Toward quality of financial report simultaneously in the amount of 90,3\% while remain 9,7\% is affected by the orther factors wich are not researched in this research. Thus this research hypothesis stated the Implmentation of Government Accounting Standards (SAP) and Internal Control System of Government on the Quality of Financial Report (SPIP) positive affected toward quality of financial report partially and simultanceous can be received and significant.
\end{abstract}

Key Word : The Implementation of Government Accounting Standard (SAP) and Internal Control System Government on the Quality of Financial Report (SPIP), Quality Financial Report.

\section{Pendahuluan}

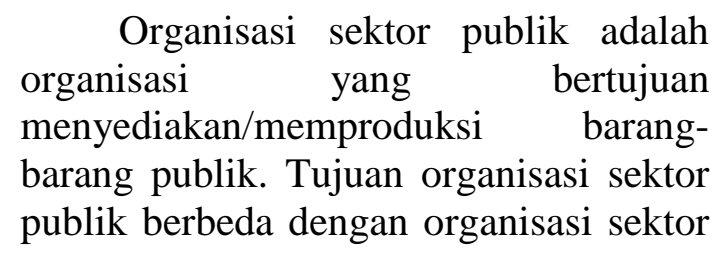

swasta. Dari sudut pandang ilmu ekonomi, sektor publik dapat dipahami sebagai suatu entitas yang aktivitasnya berhubungan dengan usaha untuk menghasilkan barang dan pelayanan publik dalam rangka memenuhi kebutuhan dan hak publik (Ulum, 2004). 
Organisasi sektor publik yang sering diidentikkan dengan pemerintahan atau badan usaha yang mayoritas kepemilikannya berada di tangan pemerintah bertanggung jawab untuk melakukan pelayanan publik untuk memenuhi kesejahteraan di berbagai bidang kehidupan seperti pendidikan, kesehatan, perekonomian, keamanan, kebebasan beragama dan beberapa hal lainnya. Reformasi dalam sistem penyelenggaraan pemerintahan negara secara mendasar telah dimulai sejak dilakukannya amandemen terhadap Undang-Undang Dasar 1945.

Organisasi sektor publik di Indonesia dalam praktiknya kini diwarnai dengan munculnya fenomena menguatnya tuntutan akuntabilitas atas organisasi-organisasi publik tersebut, baik di pusat maupun daerah. Akuntabilitas merupakan bentuk kewajiban mempertanggungjawabkan keberhasilan atau kegagalan pelaksanaan misi organisasi dalam mencapai tujuan dan sasaran yang telah ditetapkan sebelumnya, melalui suatu media pertanggungjawaban yang dilaksanakan secara periodik (Stanbury, 2003 dalam Mardiasmo, 2006).

Sebagai salah satu bentuk pertanggungjawaban dalam penyelenggaraan pemerintahan yang diatur dalam Undang-Undang Nomor 17 Tahun 2003 tentang Keuangan Negara dan Undang-Undang Nomor 32 Tahun 2004 tentang Pemerintahan Daerah. Upaya konkrit untuk mewujudkan transparansi dan akuntabilitas pengelolaan keuangan pemerintah, baik pemerintah pusat maupun pemerintah daerah adalah dengan menyampaikan laporan pertanggungjawaban berupa laporan keuangan. Laporan keuangan pemerintah yang dihasilkan harus memenuhi prinsip-prinsip tepat waktu dan disusun dengan mengikuti Standar Akuntansi Pemerintahan sesuai dengan
Peraturan Pemerintah Nomor 71 Tahun 2010.

Laporan keuangan pemerintah kemudian disampaikan kepada DPR/DPRD dan masyarakat umum setelah diaudit oleh Badan Pemeriksa Keuangan (BPK). Adapun komponen laporan keuangan yang disampaikan tersebut meliputi Laporan Realisasi Anggaran, Neraca, Laporan Arus Kas, dan Catatan atas Laporan Keuangan.

Laporan keuangan adalah catatan informasi keuangan suatu perusahaan pada suatu periode akuntansi yang dapat digunakan untuk menggambarkan kinerja perusahaan tersebut (SAK, 2009). Menurut Standar Akuntansi Keuangan yang dikeluarkan oleh Ikatan Akuntan Indonesia 2009, tujuan laporan keuangan adalah menyediakan informasi yang menyangkut posisi keuangan, kinerja, serta perubahan posisi keuangan suatu perusahaan yang bermanfaat bagi sejumlah besar pemakai dalam pengambilan keputusan. Namun demikian, laporan keuangan tidak menyediakan semua informasi yang mungkin dibutuhkan pemakai dalam mengambil keputusan ekonomi karena secara umum menggambarkan pengaruh keuangan dan kejadian masa lalu, dan tidak diwajibkan untuk menyediakan informasi.

Pengelolaan keuangan pemerintah daerah harus dilakukan berdasarkan tata kelola kepemerintahan yang baik (good government governance), yaitu pengelolaan keuangan yang dilakukan secara transparan dan akuntabel, yang memungkinkan para pemakai laporan keuangan untuk dapat mengakses informasi tentang hasil yang dicapai dalam penyelenggaraan pemerintahan daerah.

Laporan keuangan yang dihasilkan oleh pemerintah daerah akan digunakan oleh beberapa pihak yang berkepentingan sebagai dasar untuk 
pengambilan keputusan. Oleh karena itu, informasi yang terdapat di dalam Laporan Keuangan Pemerintah Daerah (LKPD) harus bermanfaat dan sesuai dengan kebutuhan para pemakai. Huang et al. (1999) dalam Xu et al. (2003) menyatakan bahwa informasi akan bermanfaat apabila informasi tersebut dapat mendukung pengambilan keputusan dan dapat dipahami oleh para pemakai. Oleh karena itu, pemerintah daerah wajib memperhatikan informasi yang disajikan dalam laporan keuangan untuk keperluan perencanaan, pengendalian, dan pengambilan keputusan. Informasi akuntansi yang terdapat di dalam laporan keuangan pemerintah daerah harus memenuhi beberapa karakteristik kualitatif yang sebagaimana disyaratkan dalam Peraturan Pemerintah No. 71 Tahun 2010 tentang Standar Akuntansi Pemerintahan, yakni relevan (manfaat umpan balik, manfaat prediktif, tepat waktu, lengkap), Andal (dapat diuji kebenarannya, netral, penyajian secara wajar/ jujur), dapat dibandingkan dan dapat dipahami.

Anggaran Pendapatan dan Belanja Negara (APBN) atau Anggaran Pendapatan dan Belanja Daerah (APBD) disusun dan disajikan dengan Standar Akuntansi Pemerintahan yang ditetapkan oleh peraturan pemerintah. Pemerintah juga mengeluarkan Undang-Undang No. 32 Tahun 2004 tentang Pemerintahan Daerah. Undang-Undang No. 33 tahun 2004 yang merubah akuntabilitas atau pertanggungjawaban pemerintah daerah dari pertanggungjawaban vertikal (kepada pemerintah pusat) ke pertanggungjawaban horizontal (kepada masyarakat melalui DPRD).

Dalam pemeriksaan keuangan negara yang meliputi pemeriksaan pengelolaan dan tanggung jawab keuangan negara, dilaksanakan oleh BPK RI. Pemeriksaan keuangan yang dilakukan oleh BPK RI pada satuan kerja di pusat dan daerah biasanya dilaksanakan pada awal tahun anggaran. Hasil dari pemeriksaan keuangan ini adalah opini hasil pemeriksaan yang merupakan pernyataan profesional pemeriksa tentang kewajaran informasi keuangan yang disajikan dalam laporan keuangan yang didasarkan pada kriteria : kesesuaian dengan standar akuntansi pemerintah; kecukupan pengungkapan; kepatuhan terhadap peraturan perundang-undangan; dan efektivitas sistem pengendalian intern. Adapun jenis opini yang diberikan oleh pemeriksa ada 4 jenis opini yaitu Wajar Tanpa Pengecualian (WTP), Wajar Dengan Pengecualian (WDP), Tidak Wajar (TP), Pernyataan Menolak memberi Opini atau Tidak Memberi Pendapat (TMP).

Berbicara mengenai pelaporan keuangan dan nilai informasi yang terkandung dalam laporan keuangan pemerintah akan menimbulkan pertanyaan apakah pelaporan keuangan pemerintah selama ini sudah memenuhi kriteria kompetensi informasi yang disyaratkan dalam peraturan perundangundangan? Apakah laporan keuangan pokok yang terdiri dari Laporan Realisasi Anggaran, Neraca, Laporan Arus Kas, dan Catatan atas Laporan Keuangan (UU No 17 Tahun 2003) telah relevan, andal, dapat dibandingkan, dan dapat dipahami.

Fenomena pelaporan keuangan pemerintah di Indonesia merupakan sesuatu hal yang menarik untuk dikaji lebih lanjut. Dari berbagai tulisan yang berhasil di-download dari internet, ternyata di dalam laporan keuangan pemerintah masih banyak disajikan datadata yang tidak sesuai. Selain itu juga masih banyak penyimpanganpenyimpangan yang berhasil ditemukan oleh Badan Pemeriksa Keuangan dalam pelaksanaan audit laporan keuangan 
pemerintah. Seperti tulisan yang berhasil dihimpun adalah sebagai berikut:

Ketua Badan Pemeriksaan Keuangan (BPK) Anwar Nasution menilai laporan keuangan Pemerintah Daerah banyak yang bermasalah bahkan tidak layak audit. Anwar Nasution menyebutkan, permasalahan yang ditemukan diantaranya terkait ketidakjelasan penyimpanan dana daerah dan penggunaan keuangan daerah dengan boros yang tidak jelas keperluannya. Anwar Nasution juga mengkritik akuntabilitas transparasi laporan keuangan Pemda masih sangat rendah (indosiar.com, 10 Januari 2007).

Masih banyaknya fenomena laporan keuangan pemerintah yang belum menyajikan data-data yang sesuai dengan peraturan dan masih banyak penyimpangan-penyimpangan yang berhasil ditemukan oleh Badan Pemeriksa Keuangan (BPK) dalam pelaksanaan audit laporan keuangan pemerintah membuat tuntutan masyarakat terhadap penyelenggaraan pemerintahan yang baik (good governance government) meningkat. Hal itu juga yang telah mendorong pemerintah pusat dan pemerintah daerah untuk menerapkan akuntabilitas publik.

Temuan-temuan tersebut menunjukkan bahwa hal pertama yang mungkin mempengaruhi kualitas laporan keuangan pemerintah daerah adalah standar akuntansi pemerintahan bertujuan untuk meningkatkan akuntabilitas dan keandalan pengelola keuangan pemerintah melalui penyusunan dan pengembangan standar akuntansi pemerintah.

Perbedaan penerapan Standar Akuntansi Pemerintahan pada masa pra reformasi dan sistem yang baru adalah sistem akuntansi penatausahaan keuangan daerah yang berlaku pada masa lalu dan saat ini tercermin dalam perhitungan APBD menggunakan sistem pembukuan tunggal yang berbasis kas. Prinsip basis kas adalah mengakui pendapatan pada saat diterimanya kas dan mengakui belanja atau biaya pada saat dikeluarkannya kas. Hal tersebut tentu saja sangat terbatas, karena informasi yang dihasilkan hanya berupa kas yang terdiri dari informasi kas masuk, kas keluar, dan saldo kas. Dengan demikian reformasi akuntansi pemerintahan di Indonesia adalah perubahan singl entry menjadi dauble entry. Single entry pada awalnya digunakan sebagai dasar pembukuan dengan alasan utama demi kemudahan dan kepraktisan. Seiring dengan tingginya tuntutan perwujudan good public governance, perubahan tersebut dipandang sebagai solusi yang mendesak untuk diterapkan karena pengaplikasian double enrty dapat menghasilkan laporan keuangan yang lengkap dan auditable (Mardiasmo: 2006).

Sebagaimana diuraikan diatas maka diperlukan pengembangan atas standar akuntansi pemerintahan yang baru, yaitu :

1. Pengembangan sistem pembukuan berganda ( Double Entry ), dimana setiap transaksi dicatat dengan jurnal berpasangan, yaitu sisi debit dan sisi kredit.

2. Penggunaan basis akrual ( Accrual Basis ) dengan mengembangkan prinsip dan asumsi bahwa pencatatan transaksi keuangan tidak hanya dilakukan pada saat terjadi penerimaan dan pengeluaran uang. Dengan basis akrual, informasi yang akan diberikan kepada pemakai tidak hanya terbatas pada transaksi masa lalu yang melibatkan penerimaan dan pengeluaran kas, melainkan juga kewajiban yang membutuhkan penyelesaian kas dimasa depan dan informasi lain yang mempresentasikan kas yang akan diterima dimasa depan. 
Hal terakhir yang mungkin
mempengaruhi kualitas laporan keuangan adalah sistem pengendalian intern pemerintah itu sendiri. pada Tahun 2008, Pemerintah mengeluarkan Peraturan Pemerintah Nomor 60 Tahun 2008 tentang Sistem Pengendalian intern Pemerintah (SPIP). Sistem Pengendalian Intern Pemerintah (SPIP) merupakan proses yang dirancang untuk memberikan keyakinan yang memadai mengenai pencapaian tujuan pemerintah yang tercermin dari keandalan laporan keuangan, efisiensi dan efektivitas pelaksanaan program dan kegiatan serta dipatuhinya peraturan perundangundangan. Dengan sistem pengendalian tersebut diharapkan dapat mencapai tujuannya, yaitu dengan laporan keuangan yang andal. Sesuai dalam Peraturan Pemerintah nomor 8 tahun 2006 tentang Pelaporan Keuangan dan Kinerja Instansi Pemerintah pasal 33 ayat (1) disebutkan bahwa " untuk meningkatkan keandalan laporan keuangan dan kinerja sebagaimana diatur dalam peraturan pemerintah ini, setiap entitas pelaporan dan akuntansi wajib menyelenggarakan sistem pengendalian intern sesuai dengan ketentuan peraturan perundangundangan terkait".

Pengaplikasian

Sistem

Pengendalian Intern Pemerintah (SPIP) pada satuan kerja dilakukan dengan menciptakan dan memelihara lingkungan pengendalian yang menimbulkan sikap dan kinerja positif pencapaian tujuan organisasi; memberikan penilaian atas risiko yang dihadapi oleh satuan kerja, baik risiko eksternal maupun internal; memastikan bahwa arahan pimpinan berkaitan dengan tujuan organisasi telah dilaksanakan secara efektif dan efisien; mengkomunikasikan informasi yang akurat dan akuntabel secara tepat waktu, memanfaatkan sarana yang efektif, dan senantiasa memperbaharui informasi sesuai perkembangan; dan melakukan pemantauan terhadap seluruh aktivitas organisasi sebagai bahan evaluasi perbaikan kinerja organisasi.

Sistem Pengendalian Intern Pemerintah (SPIP) diharapkan menjadi sistem pengendalian yang lebih menekan pada aspek soft control dan berbasis resiko terhadap pengelolaan keuangan sehingga tercipta ketaatan terhadap peraturan perundang-undangan, pengamanan aset yang tinggi, laporan keuangan yang handal, serta dapat menekan perilaku korupsi dalam pelaksanaan tugas dan fungsi.

Hasil pemeriksaan keuangan disajikan dalam tiga kategori yaitu opini, SPI dan kepatuhan terhadap ketentuan perundang-undangan. Hasil pemeriksaan BPK dituangkan dalam Laporan Hasil Pemeriksaan (LPH) dan dinyatakan dalam sejumlah temuan. Setiap temuan dapat terdiri atas satu atau lebih permasalahan kelemahan SPI dan atau ketidakpatuhan terhadap perundangundangan yang mengakibatkan kerugian negara/daerah/perusahaan, potensi kerugian negara/daerah/perusahaan, kekurangan penerimaan, penyimpangan administrasi, ketidakhematan, ketidakefisiensian, ketidakefektifan.

Pemerintah daerah Kabupaten Kuningan yang juga berkewajiban menyajikan laporan keuangan diharuskan memberi pernyataan tanggungjawab atas laporan keuangan secara jelas sesuai dengan peraturan perundang-undangan yang berlaku. Hasil Laporan pemeriksaan Badan Pemeriksa Keuangan (BPK) terhadap Laporan Keuangan Pemerintah Daerah (LKPD) Kabupaten Kuningan dari tahun 2009 2013, mendapat Opini Wajar Dengan Pengecualian (WDP) (http://www.bpk.go.id). 
Tabel 1.1

Opini BPK Atas Laporan Keuangan Kabupaten Kuningan

\begin{tabular}{|r|l|l|}
\hline \multicolumn{1}{|l|}{ NO } & TAHUN & OPINI \\
\hline 1 & 2009 & WDP \\
\hline 2 & 2010 & WDP \\
\hline 3 & 2011 & WDP \\
\hline 4 & 2012 & WDP \\
\hline 5 & 2013 & WDP \\
\hline
\end{tabular}

Sumber : http://www.bpk.go.id

Artinya dalam menyusun laporan keuangan masih ada kendala yang dihadapi dalam penerapan sistem pengelolaan laporan keuangan. BPK masih menemukan dalam penyajian laporan keuangan masih menemukan dalam penyajian laporan keuangan belum sesuai standar akuntansi pemerintah, kelemahan sistem pengendalian intern dan pelaporan yaitu kelemahan sistem pengendalian Akuntansi dan pelaporan, sistem pengendalian pelaksanaan anggaran pendapatan dan belanja dan stuktur pengendalian intern.

Secara umum dari hasil pemeriksaan tiga tahun terakhir, untuk Kabupaten Kuningan BPK masih menemukan temuan yang berulang, yang menjadi pengecualian dalam pemberian opini, yaitu temuan mengenai penyajian aset tetap, penyajian persediaan yang tidak memadai, penyajian penyertaan modal pemerintah yang tidak sesuai dengan Standar Akuntansi Pemerintahan (SAP) dan penyajian investasi non permanen dana bergulir yang belum menggunakan nilai bersih yang dapat direalisasikan (net realizable value).

Misal Opini yang diberikan BPK atas Laporan Keuangan Pemerintah Kabupaten Kuningan Tahun 2011 adalah Wajar Dengan Pengecualian (WDP). kelemahan itu berupa dalam pengendalian intern aset tetap pada Pemerintah Kabupaten Kuningan, yaitu:
(1) Nilai aset tetap yang disajikan dalam Neraca per 31 Desember 2011 berbeda dengan jumlah nilai aset tetap menurut Bagian Perlengkapan Sekretariat Daerah maupun SKPD; (2) Nilai aset tetap Dinas Pendidikan, Pemuda dan Olahraga, Dinas Kesehatan, Dinas Sumber Daya Air dan Pertambangan, Dinas Perhubungan, Badan Keluarga Berencana dan Pemberdayan Perempuan, Badan Pengelolaan Lingkungan Hidup Daerah, dan Badan Pelaksana Penyuluhan Pertanian, Perikanan dan Kehutanan senilai Rp975,11 miliar tidak disusun berdasarkan nilai aset tetap pada Unitunit Pelaksana Teknis Daerah; (3) Penambahan aset tetap yang berasal dari Belanja Modal Dana BOS (Pusat) sebesar Rp10,03 miliar tidak didukung dengan daftar rincian aset tetap yang memadai; (4) Belum seluruh aset tetap disajikan dalam Neraca, diantaranya aset tetap yang berasal dari Belanja Tak Terduga sebesar Rp3,14 miliar; (5) Penilaian aset tetap belum seluruhnya dilakukan dan aset tetap pada Dinas Kesehatan senilai Rp1,2 miliar tidak diketahui keberadaannya; (6) Aset tetap tanah Pemerintah Kabupaten Kuningan sebanyak 394 bidang seluas 3.959.147m2 belum didukung dengan bukti kepemilikan (sertifikat). (sumberhttp://Bandung.bpk.go.id)

Berdasarkan uraian di atas maka tujuan penelitian ini adalah: 
1. Untuk mengetahui bagaimana pengaruh Implementasi Standar Akuntansi Pemerintahan (SAP) dan Sistem Pengendalian Intern Pemerintah (SPIP) terhadap kualitas laporan keuangan pada Pemerintah Daerah Kabupaten Kuningan

2. Untuk mengetahui bagaimana pengaruhImplementasi Standar Akuntansi Pemerintahan (SAP) terhadap kualitas laporan keuangan pada Pemerintah Daerah Kabupaten Kuningan

3. Untuk mengetahui bagaimana pengaruh Implementasi Sistem Pengendalian Intern Pemerintah (SPIP) terhadap kualitas laporan keuangan pada Pemerintah Daerah Kabupaten Kuningan.

\section{Tinjauan Pustaka dan Hipotesis}

\section{A. Standar Akuntansi Pemerintahan (SAP)}

Definisi Standar Akuntansi Pemerintahan yang tercantum dalam Peraturan Pemerintah Republik Indonesia No71 tahun 2010 adalah :

"Sistem Akuntansi Pemerintahan adalah rangkaian sistematik dari prosedur, penyelenggara, peralatan, dan elemen lain untuk mewujudkan fungsi akuntansi sejak analisis transaksi sampai dengan pelaporan keuangan dilingkungan organisasi pemerintah".

\section{B. Sistem Pengendalian Intern Pemerintah (SPIP)}

Definisi Sistem Pengendalian Intern Pemerintah (SPIP) yang tercantum dalam Peraturan Pemerintah Republik Indonesia No 60 tahun 2008 adalah :

"Proses yang integral pada tindakan dan kegiatan yang dilakukan secara terus menerus oleh pimpinan dan seluruh pegawai untuk memberikan keyakinan memadai atas tercapainya tujuan organisasi melalui kegiatan yang efektif dan efisien, keandalan pelaporan keuangan, pengamanan aset negara, dan ketaatan terhadap peraturan perundangundangan".

\section{Kualitas Laporan Keuangan}

Pengertian Laporan Keuangan menurut Ikatan Akuntan Indonesia dalam buku "Standar Akuntansi Keuangan" menyatakan bahwa:

"Laporan Keuangan merupakan bagian dari proses pelaporan keuangan. Laporan keuangan yang lengkap biasanya meliputi Neraca, Laporan Rugi-Laba, Laporan Perubahan Posisi Keuangan (yang dapat disajikan dalam berbagai cara misalnya sebagai Laporan Arus Kas atau Laporan Arus Dana), Catatan dan laporan lain serta materi penjelasan yang merupakan bagian integral dari laporan keuangan". (2004:2)

Informasi keuangan akan bermanfaat apabila dapat memenuhi kebutuhan setiap pemakai baik pihak ekstern maupun pihak intern. Menurut Peraturan Pemerintah Republik Indonesia Nomor 71 Tahun 2010 Tentang Standar Akuntansi Pemerintah
1. Relevan
2. Andal
3. Dapat dibandingkan
4. Dapat dipahami

\section{Hipotesis}

Berdasarkan bagan pemikiran di atas, penulis mempunyai hipotesis penelitian bahwa Implementasi Standar Akuntansi Pemerintahan (SAP) dan Sistem Pengendalian Intern Pemerintah (SPIP) mempunyai pengaruh terhadap Kualitas laporan keuangan dengan uraian sebagai berikut :

1. Terdapat pengaruh positif antara Implementasi Standar Akuntansi Pemerintahan (SAP) dan Sistem 
Pengendalian Intern Pemerintah (SPIP) terhadap kualitas laporan keuangan pada Pemerintah Daerah Kabupaten Kuningan.

2. Terdapat pengaruh positif antara Implementasi Standar Akuntansi Pemerintahan (SAP) terhadap kualitas laporan keuangan pada Pemerintah Daerah Kabupaten Kuningan.

3. Terdapat pengaruh positif antara Implementasi Sistem Pengendalian Intern Pemerintah (SPIP) terhadap kualitas laporan keuangan pada Pemerintah Daerah Kabupaten Kuningan.

\section{Metodologi Penelitian}

Pada penelitian ini, metode yang digunakan adalah metode deskriptif dan verifikatif. Dengan menggunakan metode penelitian akan diketahui pengaruh yang positif atau negatif antara variabel yang diteliti sehingga menghasilkan kesimpulan yang akan memperjelas gambaran mengenai objek yang diteliti.

Metode Deskriptif menurut Sugiono (2008:21) adalah "Metode yang digunakan untuk menganalisa data dengan cara mendeskripsikan atau menggambarkan data yang telah terkumpul sebagaimana adanya tanpa membuat kesimpulan yang berlaku umum atau generalisasi."

Metode Verifikatif menurut Sugiono (2008:6) adalah "Penelitian melalui pembuktian untuk menguji hipotesis hasil penelitian deskriptif dengan suatu perhitungan statistik sehingga didapat pembuktian yang menunjukan hipotesis ditolak atau diterima".

Menurut Sambas Ali Muhidin (2011: 13), Variabel adalah karakteristik yang akan diobservasi dari satuan pengamatan.
Populasi pada penelitian ini adalah Kepala SKPD. Jumlah SKPD di Kabupaten Kuningan adalah sebanyak 37 SKPD dikalikan 1 orang menjadi 37 orang yang kemudian akan dijadikan populasi.

Sampel yang diambil menggunakan teknik sampling jenuh atau disebut juga sensus dimana semua anggota populasi dijadikan sampel, menurut Sugiyono (2009:85)

Sampling Jenuh adalah teknik penentuan sampel bila semua anggota populasi digunakan sebagai sampel." Jadi yang dijadikan sampel dalam penelitian ini adalah sebanyak 37 sampel.

Data penelitian yang digunakan adalah data Implementasi Standar Akuntansi Pemerintahan (SAP) (variabel $x_{1}$ ) dan Implementasi Sistem Pengendalian Intern Pemerintah (SPIP) (variabel $x_{2}$ ) dan kualitas Laporan keuangan (variabel y). Ditinjau dari aspek pengukurannya, data penelitian memggunakan data ordinal.

Alat ukur yang digunakan untuk mengetahui data Implementasi Standar Akuntansi Pemerintahan (SAP) $\left(\right.$ variabel $\left._{1}\right)$ dan Implementasi Sistem Pengendalian Intern Pemerintah (SPIP) (variabel $x_{2}$ ) dan kualitas Laporan keuangan (variabel y) menggunakan teknik skala Likert.

Menurut Nur Indriantoro dan Bambang Supomo (2002:104) “ Skala likert merupakan metode yang mengukur sikap dengan menggunakan setuju atau ketidak setujuan-nya terhadap subjek, obyek atau kejadian tertentu". Sedangkan menurut Sugiyono (2009:93) "Skala Likert digunakan untuk mengukur sikap, pendapat, dan persepsi seseorang atau sekelompok orang tentang fenomena sosial".

Jawaban setiap item instrumen yang menggunakan skala likert mempunyai gradasi dari sangat positif 
sampai sangat negatif, yang dapat berupa kata-kata sangat setuju, setuju, ragu-ragu, tidak setuju dan sangat tidak setuju. Untuk keperluan analisis kuantitatif, maka jawaban itu dapat diberi skor 5-4-3-2-1.

Sumber data penelitian yang digunakan ditinjau dari aspek cara memperolehnya adalah data primer, menurut Sambas Ali Muhidin dan Maman Aburahman (2009:17) "data Primer adalah data disaat dan diolah langsung dari objeknya".

Untuk data primer penulis memperoleh data dari Setda kabupaten Kuningan, diantaranya adalah: hasil audit laporan keuangan, bagan struktur organisasi pemerintahan, dan lain-lain.

Adapun yang dijadikan dasar sumber data dalam penelitian ini adalah pegawai di bagian keuangan terkait kualitas laporan keuangan Pemerintah Daerah Kabupaten Kuningan.

\section{Teknik Analisa Data Uji Validitas}

Menurut Sugiyono (2009:121) "Valid berarti instrumen tersebut dapat digunakan untuk mengukur apa yang seharusnya diukur".

\section{Uji Reliabilitas}

Menurut Sugiyono (2009:121) "Instrumen yang reliabel adalah instrumen yang bila digunakan beberapa kali untuk mengukur obyek yang sama, akan menghasilkan data yang sama”.
Dalam penelitian ini instrumen yang digunakan adalah kuesioner dengan format rating scale. Keseluruhan jawaban diklasifikasikan ke dalam 5 (lima) kategori, sebagai berikut :

a. Untuk Alternatif jawaban (a) diberi nilai atau skor 5, yang berarti sangat setuju

b. Untuk Alternatif jawaban (b) diberi nilai atau skor 4, yang berarti setuju

c. Untuk Alternatif jawaban (c) diberi nilai atau skor 3, yang berarti kurang setuju

d. Untuk Alternatif jawaban (d) diberi nilai atau skor 2 , yang berarti tidak setuju

e. Untuk Alternatif jawaban (e) diberi nilai atau skor 1 , yang berarti tidak setuju

Sehubungan dengan pengukuran data berskala ordinal, maka skala tersebut harus dinaikan dulu menjadi skala interval dengan menggunakan "Metode Succesive Interval" atau Methode ofSuccesive Interval" dengan rumus sebagai berikut :

Sehubungan pengukuran data berskala ordinal, maka skala tersebut harus dinaikkan dulu menjadi skala interval dengan menggunakan "Metode Succesive Interval" dengan langkahLangkah sebagai berikut :

Berdasarkan pengkategorian skala interval tersebut disusun kriteria penilaian berdasarkan prosentasi sebagai berikut :

$$
\begin{array}{|c|l|l|l|l|}
\hline \frac{4,24}{5} \mathrm{X} 100 \%=84,8 & \frac{3,43}{5} \mathrm{X} 100 \%=68,8 & \frac{2,62}{5} \times 100 \%=52,3 & \frac{1,81}{5} \times 100 \%=36,2 \\
\hline
\end{array}
$$

Dari perolehan hasil

tersebut, maka untuk menentukan pengkategorian derajat baik atau tidak baik variabel yang diteliti melalui analisis sebagai berikut :
- $84,8 \%$ - $100 \%$ termasuk klasifikasi sangat baik

- $68,8 \%-84,7 \%$ termasuk klasifikasi baik

- 52,4\% - 68,7\% termasuk klasifikasi cukup baik 
- $36,2 \%-52,3 \%$ termasuk klasifikasi tidak baik

- $0,00 \%-36,1 \%$ termasuk klasifikasi sangat tidak baik

\section{Analisis Korelasi Spearman Rank}

Pengujian korelasi digunakan untuk mengetahui kekuatan hubungan korelasi antara Implementasi Standar Akuntansi Pemerintahan (SAP) dan Implementasi Sistem Pengendalian Intern Pemerintah (SPIP) terhadap Kualitas Laporan Keuangan pada Pemerintah Kabupaten Kuningan. Adapun pengujian korelasi yang digunakan adalah korelasi Rank Sperman.

\section{Koefisien Determinasi}

$\begin{array}{lr}\text { Koefisien determinasi } & \left(\mathrm{R}^{2}\right) \text { pada } \\ \text { intinya mengukur } & \text { seberapa } \\ \text { jauhkemampuan model } & \text { dalam } \\ \text { menerangkan variasi } & \text { variabel } \\ \text { dependen.Nilaikoefisien } & \text { determinasi } \\ \text { antara nol dan satu. }\end{array}$

\section{Uji Hipotesis}

Uji Simultan

Uji Simultan dapat digunakan untuk menguji hipotesis pengaruh Standar Akuntansi Pemerintahan $\left(\mathrm{X}_{1}\right)$, Sistem Pengendalian Intern Pemerintah $\left(\mathrm{X}_{2}\right)$ terhadap Kualitas Laporan Keuangan (Y) secara bersama-sama.

\section{Uji Parsial}

UjiParsial digunakan untuk menguji hipotesis 1 dan 2 untuk menguji pengaruh Standar Akuntansi Pemerintahan $\left(\mathrm{X}_{1}\right)$ dan Sistem Pengendalian Intern Pemerintah $\left(\mathrm{X}_{2}\right)$ terhadap Kualitas Laporan Keuangan (Y) secara parsial.

\section{Hasil Penelitian dan Pembahasan Hasil Penelitian Uji Validitas dan Uji Reabilitas Variabel implementasi Standar Akuntansi Pemerintahan $\left(\mathbf{X}_{1}\right)$}

Untuk mengetahui validitas dan realibilitas instrument pada variabel implementasi Standar Akuntansi Pemerintahan $\left(\mathrm{X}_{1}\right)$, dilakukan dengan menggunakan bantuan fasilitas SPSS Release 16. Data variabel tersebut berupa data ordinal dari hasil sebaran angket dengan jumlah 20 responden dengan jumlah item sebanyak 15 (lima belas) pernyataan.

Berdasarkan hasil perhitungan, dapat dilihat bahwa ada 5 item instrument variabel $\mathrm{X}_{1}$ (Varibel implementasi Standar Akuntansi Pemerintahan) yang dinyatakan tidak valid dan 10 item instrument variabel $\mathrm{X}_{1}$ (Varibel implementasi Standar Akuntansi Pemerintahan) yang dinyatakan valid. Butir instrumen variabel tersebut dinyatakan tidak valid karena nilai $r_{\text {hitung }}$ yang dihasilkan lebih kecil dari $r_{\text {tabel }}$ sebesar 0,514 untuk $\mathrm{N}=15$ dengan taraf signifikansi 5\% dan butir instrumen variabel dinyatakan valid karena nilai $r_{\text {hitung }}$ yang dihasilkan lebih besar dari $r_{\text {tabel }}$ sebesar 0,514 untuk $\mathrm{N}=15$ dengan taraf signifikansi $5 \%$.

Untuk melakukan uji reliabilitas Varibel implementasi Standar Akuntansi Pemerintahan $\left(\mathrm{X}_{1}\right)$ dengan nilai $r_{\text {tabel }}$ sebesar 0,514 untuk $\mathrm{N}=15$ dan taraf signifikansi 5\%, diperoleh nilai alpha (Cronbach Alpha)sebesar 0,850. Sehingga dapat disimpulkan bahwa nilai yang dihasilkan lebih besar dari nilai tabel ratau $0,850>0,514$ artinya instrumen angket dinyatakan reliabel.

\section{Variabel Implementasi Sistem Pengendalian Intern Pemerintah $\left(\mathbf{X}_{2}\right)$}

Untuk mengetahui validitas dan realibilitas instrument pada variabel ImplementasiSistem Pengendalian Intern Pemerintah $\left(\mathrm{X}_{2}\right)$, dilakukan dengan menggunakan bantuan fasilitas SPSS Release 16. Data variabel tersebut 
berupa data ordinal dari hasil sebaran angket dengan jumlah 20 responden dengan jumlah item sebanyak 15 (lima belas) pernyataan.

Berdasarkan perhitungan dapat dilihat bahwa ada 4 item instrument variabel $\mathrm{X}_{2}$ (Varibel Implementasi Sistem Pengendalian Intern Pemerintah) yang dinyatakan tidak valid dan 11 item instrument variabel $\mathrm{X}_{2} \quad$ (Varibel Implementasi Sistem Pengendalian Intern Pemerintah) yang dinyatakan valid. Butir instrumen variabel tersebut dinyatakan tidak valid karena nilai $r_{\text {hitung }}$ yang dihasilkan lebih kecil dari $r_{\text {tabel }}$ sebesar 0,514 untuk $\mathrm{N}=15$ dengan taraf signifikansi $5 \%$ dan butir instrumen variabel dinyatakan valid karena nilai

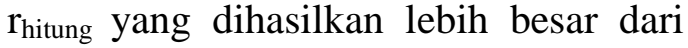
$\mathrm{r}_{\text {tabel }}$ sebesar 0,514 untuk $\mathrm{N}=15$ dengan taraf signifikansi $5 \%$.

Dari tabel diatas, untuk uji reliabilitas Varibel ImplementasiSistem Pengendalian Intern Pemerintah $\left(\mathrm{X}_{2}\right)$ dengan nilai $r_{\text {tabel }}$ sebesar 0,514 untuk $\mathrm{N}=150$ dan taraf signifikansi 5\%, diperoleh nilai alpha (Cronbach Alpha)sebesar 0,849. Sehingga dapat disimpulkan bahwa nilai yang dihasilkan lebih besar dari nilai tabel $\mathrm{r}$ atau 0,849>0,514 artinya instrumen angket dinyatakan reliabel.

\section{Variabel kualitas laporan keuangan}

(Y)
Data variabel Y (variabel kualitas laporan keuangan) tersebut berupa data ordinal dari hasil sebaran angket dengan jumlah 20 responden dengan jumlah item sebanyak 15 (lima belas) pernyataan.

Berdasarkan Perhitungan, dapat dilihat bahwa ada 4 item instrument variabel kualitas laporan keuangan (Y) yang dinyatakan tidak valid dan 11 item instrument variabel kualitas laporan keuangan (Y) yang dinyatakan valid. Butir instrumen variabel tersebut dinyatakan tidak valid karena nilai $r_{\text {hitung }}$ yang dihasilkan lebih kecil dari $r_{\text {tabel }}$ sebesar 0,514 untuk $\mathrm{N}=15$ dengan taraf signifikansi $5 \%$ dan butir instrumen variabel dinyatakan valid karena nilai $\mathrm{r}_{\text {hitung }}$ yang dihasilkan lebih besar dari $r_{\text {tabel }}$ sebesar 0,514 untuk $\mathrm{N}=15$ dengan taraf signifikansi 5\%.

Dari tabel diatas, untuk uji reliabilitas variabel kualitas laporan keuangan ( $\mathrm{Y}$ ) dengan nilai $\mathrm{r}_{\text {tabel }}$ sebesar 0,514 untuk $\mathrm{N}=15$ dan taraf signifikansi 5\%, diperoleh nilai alpha (Cronbach Alph) sebesar 0,936. Sehingga dapat disimpulkan bahwa nilai yang dihasilkan lebih besar dari nilai tabel $\mathrm{r}$ atau 0,936>0,514 artinya instrumen angket dinyatakan reliabel.

\section{Analisis Korelasi Spearman Rank}

Tabel

Korelasi Implementasi Standar Akuntansi Pemerintahan (SAP) dan Sistem Pengendalian Intern Pemerintah (SPIP) terhadap kualitas laporan keuangan pada Pemerintah Daerah Kabupaten Kuningan Dengan Program SPSS

\section{Correlations}

\begin{tabular}{|r|r|r|r|}
\hline & $\begin{array}{c}\text { Implement } \\
\text { asi SAP }\end{array}$ & $\begin{array}{c}\text { Kualitas } \\
\text { Implement } \\
\text { asi SPIP }\end{array}$ & $\begin{array}{c}\text { Laporan } \\
\text { Keuangan }\end{array}$ \\
\hline $\begin{array}{r}\text { Spea Implement } \\
\text { rman's rho asi SAP Correl }\end{array}$ & 1.000 & $.725^{*}$ & $.831^{* *}$ \\
\hline
\end{tabular}




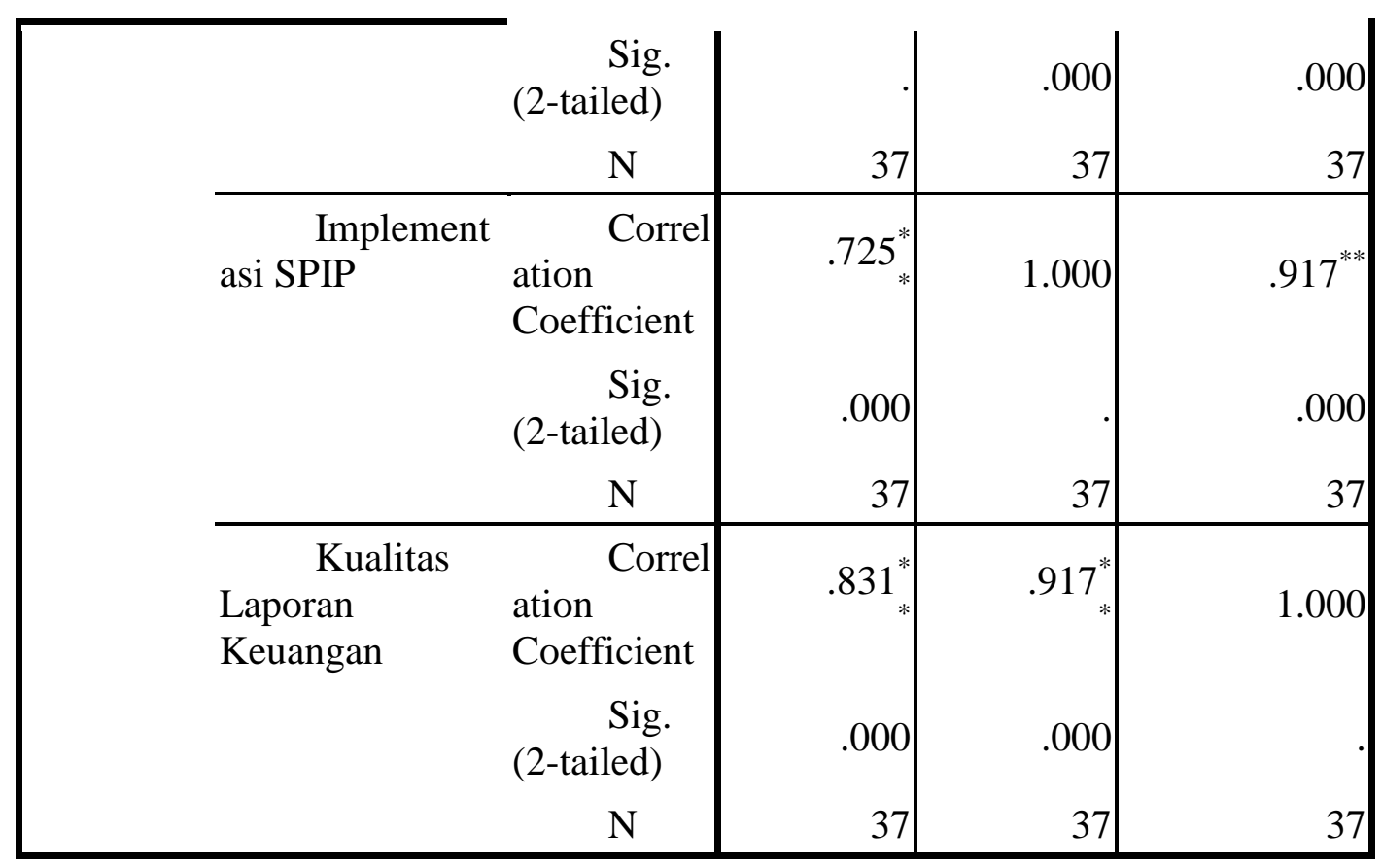

**. Correlation is significant at the

0.01 level (2-tailed).

Korelasi Spearman Rank $\left(\mathrm{R}_{\mathrm{s}}\right)$ positif yang sangat kuatantara untuk Variabel implementasi Standar Akuntansi Pemerintahan $\left(\mathrm{X}_{1}\right)$ dengan kualitas laporan keuangan (Y) sebesar 0,831 berati terdapat hubungan positif yang sangat kuat antara Implementasi Standar Akuntansi Pemerintahan (SAP) dengan kualitas laporan keuangan. Sedangkan untuk variabel Sistem Pengendalian Intern Pemerintah $\left(\mathrm{X}_{2}\right)$ dengan kualitas laporan keuangan (Y) sebesar 0,917 berarti terdapat hubungan Implementasi Sistem Pengendalian Intern Pemerintah (SPIP) dengan kualitas laporan keuangan.

Besarnya Koefisien Korelasi secara keseluruhan yang menunjukan hubungan antara Implementasi Standar Akuntansi Pemerintahan (SAP) dan Sistem Pengendalian Intern Pemerintah (SPIP) terhadap kualitas laporan keuangan dapat dilihat pada tabel berikut:

Tabel

Hasil Koefisien Korelasi antara Implementasi Standar Akuntansi Pemerintahan (SAP) dan Sistem Pengendalian Intern Pemerintah (SPIP) terhadap Kualitas Laporan Keuangan pada Pemerintah Daerah Kabupaten Kuningan Dengan Program SPSS

Model Summary

\begin{tabular}{|c|c|c|c|c|c|c|c|c|c|}
\hline \multirow[b]{2}{*}{ odel } & \multirow[b]{2}{*}{$\mathrm{R}$} & \multirow[b]{2}{*}{$\begin{array}{r}\mathrm{R} \\
\text { Square }\end{array}$} & \multirow[b]{2}{*}{$\begin{array}{l}\text { Adju } \\
\text { sted R } \\
\text { Square }\end{array}$} & \multirow{2}{*}{$\begin{array}{l}\text { Std. } \\
\text { Error of } \\
\text { the } \\
\text { Estimate }\end{array}$} & \multicolumn{5}{|c|}{ Change Statistics } \\
\hline & & & & & $\begin{array}{r}\mathrm{R} \\
\text { Square } \\
\text { Change }\end{array}$ & $\begin{array}{r}\mathrm{F} \\
\text { Change }\end{array}$ & $\mathrm{f} 1{ }^{\mathrm{d}}$ & $\mathrm{f} 2^{\mathrm{d}}$ & $\begin{array}{r}\text { Sig. } \\
\text { F Change }\end{array}$ \\
\hline & $\begin{array}{r}9 \\
50^{\mathrm{a}}\end{array}$ & $\begin{array}{r}.9 \\
03\end{array}$ & .897 & 1.217 & .903 & $\begin{array}{r}15 \\
7.403\end{array}$ & 2 & $\begin{array}{l}3 \\
4\end{array}$ & .000 \\
\hline
\end{tabular}


Model Summary

\begin{tabular}{|c|c|c|c|c|c|c|c|c|c|}
\hline \multirow[b]{2}{*}{ odel } & \multirow[b]{2}{*}{$\mathrm{R}$} & \multirow[b]{2}{*}{$\begin{array}{r}\mathrm{R} \\
\text { Square }\end{array}$} & \multirow[b]{2}{*}{$\begin{array}{l}\text { Adju } \\
\text { sted R } \\
\text { Square }\end{array}$} & \multirow{2}{*}{$\begin{array}{l}\text { Std. } \\
\text { Error of } \\
\text { the } \\
\text { Estimate }\end{array}$} & \multicolumn{5}{|c|}{ Change Statistics } \\
\hline & & & & & $\begin{array}{r}\mathrm{R} \\
\text { Square } \\
\text { Change }\end{array}$ & $\begin{array}{r}\mathrm{F} \\
\text { Change }\end{array}$ & $\mathrm{f} 1^{\mathrm{d}}$ & $\mathrm{f} 2^{\mathrm{d}}$ & $\begin{array}{r}\text { Sig. } \\
\text { F Change }\end{array}$ \\
\hline & $\begin{array}{r}9 \\
50^{\mathrm{a}}\end{array}$ & $\begin{array}{r}.9 \\
03\end{array}$ & .897 & 1.217 & .903 & $\begin{array}{r}15 \\
7.403\end{array}$ & 2 & $\begin{array}{l}3 \\
4\end{array}$ & .000 \\
\hline
\end{tabular}

a. Predictors: (Constant), Implementasi SPIP, Implementasi SAP

Berdasarkan Tabel diatas diperoleh koefisien korelasi ( $\mathrm{r}$ ) 0,950. Hal ini menunjukan bahwa terdapat hubungan positif yang sangat kuat antara Implementasi Standar Akuntansi Pemerintahan (SAP) dan Sistem Pengendalian Intern Pemerintah (SPIP) terhadap kualitas laporan keuangan.

\section{Koefisien Determinasi}

Hasil koefisien determinasi $\left(\mathrm{r}^{2}\right)$ sebesar 0,903. Hal ini menunjukkan bahwa secara simultan ada pengaruh positif yang diberikan oleh variabel Implementasi Standar Akuntansi Pemerintahan (SAP) dan Sistem Pengendalian Intern Pemerintah (SPIP) terhadap kualitas laporan keuangan sebesar 90,30\%, sedangkan sisanya 9,70\% dipengaruhi oleh faktor lain yang tidak diteliti dalam penelitian ini.

\section{Uji Hipotesis \\ Uji Simultan}

Tabel

Uji Keberartian model persamaan regresi antara Tingkat Implementasi Standar Akuntansi Pemerintahan (SAP) dan Sistem Pengendalian Intern Pemerintah (SPIP) terhadap kualitas laporan keuangandengan menggunakanProgram SPSS

ANOVA $^{\mathrm{D}}$

\begin{tabular}{|c|c|c|c|c|c|c|}
\hline Model & & $\begin{array}{l}\text { Sum of } \\
\text { Squares }\end{array}$ & Df & $\begin{array}{l}\text { Mean } \\
\text { Square }\end{array}$ & $\mathrm{F}$ & Sig. \\
\hline 1 ssion & Regre & 466.337 & 2 & 233.168 & $\begin{array}{l}157 \\
403\end{array}$ & $\begin{array}{r}.00 \\
0^{\mathrm{a}}\end{array}$ \\
\hline al & Residu & 50.366 & 34 & 1.481 & & \\
\hline & Total & 516.703 & 36 & & & \\
\hline
\end{tabular}

a. Predictors: (Constant), Implementasi SPIP, Implementasi SAP

b. Dependent Variable: Kualitas Laporan Keuangan

Uji F di dapat $F$ hitung lebih besar dari $\mathrm{F}$ tabel $(157,403>4,13)$ artinya Ho ditolak dan $\mathrm{Ha}$ diterima sehingga kesimpulannya bahwa pada tingkat signifikansi $95 \%$, Tingkat Implementasi Standar Akuntansi Pemerintahan (SAP) dan Sistem
Pengendalian Intern Pemerintah (SPIP) secara simultan ada pengaruh yang signifikan terhadap kualitas laporan keuangan. Jika dilihat pada kurva berada pada daerah penolakan Ho, seperti gambar berikut ini : 
Model regresi diuji keberartiannya dengan mengunakan uji $F$ sehingga diperoleh $\mathrm{F}$ hitung sebesar 157,403 dengan probabilitas 0,000 . Probabilitas tersebut lebih kecil daripada taraf kesalahan 0,05, yang berarti bahwa

\subsection{Uji Parsial}

Implementasi Standar Akuntansi Pemerintahan $\left(\mathrm{X}_{1}\right)$ dan Sistem Pengendalian Intern Pemerintah $\left(\mathrm{X}_{2}\right)$ adanya pengaruh yang signifikan terhadap kualitas laporan keuangan (Y).

\begin{tabular}{|c|c|c|c|c|c|c|}
\hline \multicolumn{7}{|c|}{ Coefficients $\mathrm{s}^{\mathrm{a}}$} \\
\hline \multirow[b]{2}{*}{ Mod } & & \multicolumn{2}{|c|}{$\begin{array}{l}\text { Unstandardized } \\
\text { Coefficients }\end{array}$} & \multirow{2}{*}{$\begin{array}{r}\begin{array}{c}\text { Stand } \\
\text { ardized } \\
\text { Coefficients }\end{array} \\
\text { Beta } \\
\end{array}$} & \multirow[b]{2}{*}{$\mathrm{T}$} & \multirow[b]{2}{*}{ g. ${ }^{\mathrm{Si}}$} \\
\hline & & B & $\begin{array}{l}\text { Std. } \\
\text { Error }\end{array}$ & & & \\
\hline \multirow[t]{3}{*}{1} & (Constant) & & $\begin{array}{r}4.04 \\
2\end{array}$ & & 2.212 & $\begin{array}{r}.0 \\
34\end{array}$ \\
\hline & Implementasi SAP & .415 & .092 & .391 & $\begin{array}{r}4 . \\
510\end{array}$ & $\begin{array}{l}.0 \\
00\end{array}$ \\
\hline & Implementasi SPIP & .720 & .102 & .612 & $\begin{array}{r}7 . \\
063\end{array}$ & $\begin{array}{l}.0 \\
00\end{array}$ \\
\hline
\end{tabular}

a. Dependent Variable: Kualitas Laporan Keuangan

Uji parsial yang pertama yaitu dengan membandingkan antara thitung dengan $t$ tabel, th $>\mathrm{t}$ adf4,510 >2,032) artinya Ho ditolak dan $\mathrm{Ha}$ diterima sehingga kesimpulannya bahwa Implementasi Standar Akuntansi Pemerintahan (SAP) secara parsial ada pengaruh yang signifikan terhadap kualitas laporan keuangan.

Model persamaan secara parsial diuji keberartiannya menggunakan uji $\mathrm{t}$ dan diperoleh $t$ untuk variabel ImplementasiStandar Akuntansi Pemerintahan (SAP) sebesar 4,510 dengan probabilitas $0,000<0,05$, yang berarti variabel tersebut signifikan. Hal ini juga menunjukkan adanya pengaruh yang signifikan antara Implementasi Standar Akuntansi Pemerintahan (SAP) terhadap kualitas laporan keuangan.

Uji parsial yang kedua yaitu dengan membandingkan antara $t$ hitung dengan t tabel. Dari perhitungan SPSS (lihat tabel 4.12) di dapat $\mathrm{t}$ hitung sebesar 7.063 maka th> t $\alpha \operatorname{df}(7.063$ >2,032) artinya Ho ditolak dan $\mathrm{Ha}$ diterima sehingga kesimpulannya bahwa Implementasi Sistem Pengendalian Intern Pemerintah (SPIP) secara parsial ada pengaruh yang signifikan terhadap kualitas laporan keuangan.

Nilai $t$ untuk variabel Implementasi Sistem Pengendalian Intern Pemerintah (SPIP) diperoleh sebesar 7,063 dengan probabilitas 0,000 $<0,05$, yang berarti bahwa variabel tersebut juga signifikan, sehingga dapat disimpulkan bahwa Implementasi Sistem Pengendalian Intern Pemerintah (SPIP) terdapat pengaruh yang signifikan terhadap kualitas laporan keuangan.

\section{Kesimpulan dan Saran Kesimpulan}

1. Adanya pengaruh positif antara Implementasi Standar Akuntansi Pemerintahan (SAP) dan Sistem Pengendalian Intern Pemerintah (SPIP) terhadap kualitas laporan keuangan di SKPD Pemerintah Daerah Kabupaten kuningan yaitu sebesar 90,30\% sedangkan sisanya 9,7\% dipengaruhi oleh faktor lain 
yang tidak diteliti dalam penelitian ini, hal ini berarti secara bersamasama penerapan Standar Akuntansi Pemerintahan (SAP) dan Sistem Pengendalian Intern Pemerintah (SPIP) secara efektf dan efisien dapat meningkatkan kualitas laporan keuangan.

2. Adanya pengaruh positif antara Implementasi Standar Akuntansi Pemerintahan (SAP) terhadap kualitas laporan keuangan pada Pemerintah Daerah Kabupaten Kuningan, hal ini berarti terdapat peningkatan kualitas pelaporan keuangan di pemerintahan pusat dan daerah. Dengan demikian informasi keuangan pemerintahan akan dapat menjadi dasar pengambilan keputusan di pemerintahan dan juga terwujudnya transparansi serta akuntabilitas.

3. Adanya pengaruh positif antara Implementasi Sistem Pengendalian Intern Pemerintah (SPIP) terhadap kualitas laporan keuangan pada Pemerintah Daerah Kabupaten Kuningan, hal ini berarti terdapat peningkatan sistem pengendalian intern pada suatu instansi pemerintah sehingga dapat mencapai tujuannya secara efisien dan efektif, dalam melaporkan pengelolaan kekayaan negara secara andal dan mengamankan aset negara dengan mendorong ketaatan terhadap peraturan perundang-undangan.

\section{Saran}

1. Adanya pengaruh positif antara Implementasi Standar Akuntansi Pemerintahan (SAP) terhadap kualitas laporan keuangan, namun diharapkan implementasinya dapat lebih dioptimalkan lagi sesuai dengan Standar Akuntansi Pemerintahan (SAP) yang berlaku sehingga sistem akuntansinya lebih berguna dalam pengambilan keputusan dan lebih mendatangkan manfaat bagi manajemen.

2. Adanya pengaruh positif antara Implementasi Sistem Pengendalian Intern Pemerintah (SPIP) terhadap kualitas laporan keuangan, namun diharapkan implementasinya dilakukan lebih efektif dan efesien agar terciptanya kualitas laporan keuangan yang lebih dapat dipahami, relevan, andal dan dapat dibandingkan, sehingga aset negara menjadi lebih aman dan ketentuan perundang-undangan yang berlaku juga dipatuhi.

3. Karena hasil penelitian masih ada $8 \%$ pengaruh faktor lain terhadap kualitas laporan keuangan, maka bagi peneliti lain yang bermaksud meneliti hal yang sama disarankan untuk meneliti pengaruh faktor tersebut misalnya: pengaruh penerapan sistem komputerisasi, Sumber Daya Manusia atau kebijakan manajemen.

\section{DAFTAR PUSTAKA}

Abdul Halim, 2007. Akuntansi Setor Publik, Akuntansi Keuangan Daerah,Edisi ketiga, salemba empat, Jakarta

Mardiasmo. 2006. Perwujudan Transparansi dan Akuntabilitas Publik Melalui Akuntansi Sektor Publik: Suatu Sarana Good Governance. Jurnal Akuntansi Pemerintah, Vol. 2 No.1, Hal 117.

Partono. 2000. Laporan Keuangan Pemerintah Upaya Menuju Transparansi dan Akuntabilitas. Media Akuntansi . Edisi 14. Oktober. Pp. 25 - 26.

Indra Bastian, 2005. Akuntansi Sektor Publik: Suatu Pengantar, Edisi Kesatu, Erlangga, Jakarta 
Republik Indonesia, Peraturan KementerianKeuangan RI No. 71 Tahun 2010 Tentang Standar Akuntansi

Pemerintah RepublikIndonesia, Peraturan Pemerintah RI No60 Tahun 2008 Tentang Sistem Pengendalian Intern Pemerintah Sambas Ali, Maman Abdurahman, 2007. Analisi Korelasi Regresi Dan Jalur Dalam Penelitian, Edisi kedua, CV Pustaka Setia, Bandung

Sugiyono. 2007. Statistik untuk Penelitian, Alfabeta Bandung.

Uhar Suharsaputra, 2012. Metode Penelitian Kuantitatif Kualitatif dan Tindakan, Edisi kesatu, PT. Refika Aditama, Bandung Prof.Dr.Hj.Sedarmayanti,MPd.,APU, 2007. Manajemen Sumber Daya Manusia, Edisi kesatu, PT. Refika Aditama, Bandung.

Sugiyono, 2008. Metode Penelitian Bisnis. Cetakan keduabelas 2008. Penerbit Alfabeta, Bandung. 